\title{
Popularizing Liquefied Petroleum Gas (LPG) as an Alternative to Piped Natural Gas for Domestic Use: Bangladesh Perspective
}

\author{
Engr. Md. Anisur Rahman ${ }^{1,{ }^{*}}$, Engr. Md. Ariful Islam ${ }^{1}$, and Dr. A K M Nazrul Islam ${ }^{2}$ \\ ${ }^{1}$ Planning Department, Titas Gas Transmission and Distribution Company Limited, 105 Kazi Nazrul \\ Islam Avenue, Kawran Bazar, Dhaka - 1215. \\ ${ }^{2}$ Dhaka School of Economics (DScE), Dhaka-1000.
}

\begin{abstract}
The basic objective of this paper has been to carry out comparative cost analyses for popularizing Liquefied Petroleum Gas (LPG) as a commensurate alternative to piped natural gas for domestic use in Bangladesh. Costing of LPG in three alternative scenarios of LPG utilization-LPG in cylinder, LPG supply in pipeline network for certain area and LPG in reticulated system-have been studied. Pricing of LPG and piped natural gas for domestic use have also been studied so as to recommend cross-subsidy option in LPG pricing that involves raising the price of natural gas for domestic use in order to finance LPG for expected lowering of its price, thus ensuring its access to the common people of the country. Reticulated LPG option, a semi-automatic system, has been found to be suitable as an alternative to piped natural gas for domestic use in terms of cost, flexibility and safety consideration.
\end{abstract}

Keywords: Natural Gas; LPG, Bangladesh, Domestic use

\section{Introduction}

At present most of the natural gas users for domestic purpose are non-metered. They pay gas bill as a fixed BDT 800 for whatever quantity of gas they consume. This renders most of the domestic users to pay no heed to the efficient utilization of natural gas, resulting in the wastage of natural gas, a non-renewable natural resource of Bangladesh. Some fraudulent users indulge in gas pilferage, as well as use additional gas appliances, for which they do not pay. Domestic consumers pay gas bill amounting to BDT 800/month for each double burner for whatever the quantity of gas they use. According to the flat rate of domestic gas (BDT 9.10 per cubic meter), consumers should not use more gas than 87.91cubic meters per month, while the average use of the domestic customers with prepaid meters under the Titas Franchise Area (TFA) is about 67 cubic meters per month.

There has been a significant rise in gas demand since the beginning of the year 2008; but the production was not at par with the increasing demand. This unavoidable demand-supply gap causes a serious shortfall of gas supply in the whole gas distribution system of the country.

In order to bridge this demand-supply gap, the Government of the People's Republic of Bangladesh has undertaken several meaningful steps. From July 2010 to June 2013, approvals of new gas connections were totally stopped. Later on the Government permitted new gas connections and load extension for a certain period and now a ban on these is prevailing. Only $5 \%$ of the total population of the country has access to natural gas as a domestic fuel, remaining $95 \%$ depends on biomass, coal, charcoal, wood, LPG, etc., which are expensive compared to natural gas [1]. As per the Constitution of Bangladesh, all of the citizens of the country should enjoy the same right of access to this indigenous natural resource. It is an obligation of the government to bridge the disparity among the citizens of the country regarding energy usage. Easy, safe and cheap access to LPG may be deemed as an important tool for the Government as to do this.

\section{LPG as an Alternative to Piped Natural Gas in Bangladesh}

LPG is an exceptional energy source due to its origin, benefit and application. It is very popular as a domestic fuel because of its immediate and global availability, clear environmental benefits, transportation flexibility and diverse application. Sources of LPG are crude oil refining, natural gas extraction, hydrocarbon $(\mathrm{HC})$ compounds reforming and higher $\mathrm{HC}$ molecules cracking. LPG is a mixture of propane and butane. It is a colorless liquid under pressure, but a gas at ambient conditions. LPG is approximately half as dense as water. One volume of liquid transforms into approximately 250 volumes of vapor at ambient conditions. LPG has hazards as well. It is approximately twice as heavy as air, causes severe cold burns to the skin, forms a flammable mixture

Corresponding author: Engr. Md. Anisur Rahman,

E-mail: anismba07@yahoo.com 
with air in $2 \%$ to $10 \%$ level of concentration, highly flammable gas, fire can occur when using, handling and transporting [2].Care must be taken to avoid sources of ignition and mixing with oxygen.

Table1. Comparison of physical properties of natural gas and LPG [2]

\begin{tabular}{lcc}
\hline $\begin{array}{c}\text { Physical } \\
\text { Properties }\end{array}$ & $\begin{array}{c}\text { Natural } \\
\text { Gas }\end{array}$ & LPG \\
\hline Specific Gravity & 0.6 & $1.5-2$ \\
Flammability Limit & $5 \%$ to $15 \%$ & $1.8 \%$ to \\
Auto-ignition & $550-580$ & $410-580$ \\
temperature & deg. C & deg. C \\
Higher Calorific & 12900 & 11920 \\
Value & $\mathrm{kcal} / \mathrm{kg}$ & $\mathrm{kcal} / \mathrm{kg}$ \\
Lower Calorific & 11800 & 10997 \\
Value & $\mathrm{kcal} / \mathrm{kg}$ & $\mathrm{kcal} / \mathrm{kg}$ \\
\hline
\end{tabular}

\section{Determination of LPG Requirement with Respect to Heating Value and Existing Gas Consumption of Domestic Natural Gas Consumers}

Present gas consumption of double burner cook stove $=87.91 \mathrm{CM}$ or $63.24 \mathrm{~kg} / \mathrm{month}$.

The equivalent $\mathrm{HCV}$ of natural gas $=63.24 \times$ $12900 \mathrm{kcal} / \mathrm{month}=815796 \mathrm{kcal} / \mathrm{month}$

The LPG requirement of a double burner cook stove (With respect to present natural gas consumption) $=815796 / 11920 \mathrm{~kg} / \mathrm{month}$

$=68.44 \mathrm{~kg} / \mathrm{month}$

Titas Gas Transmission and Distribution Company (TGTDCL) has already introduced 13,100 pre-paid meters for its domestic customers and installation of 2 lac pre-paid meters for its domestic customers is going on under a JICA-financed project titled
"Installation of Pre-paid Meters for TGTDCL" [3]. Pre-paid metering system ensures efficient utilization of natural gas by means of changing the gas utilization behavior of the domestic users of gas. The average monthly natural gas consumption through prepaid meters has been found to be 67 cubic meters [4].

Present gas consumption of double burner cook stove $=67 \mathrm{CM}$ or $48.20 \mathrm{~kg} / \mathrm{month}$

The equivalent $\mathrm{HCV}$ of natural gas $=48.20 \times 12900 \mathrm{kcal} / \mathrm{month}$ $=621780 \mathrm{kcal} / \mathrm{month}$

The LPG requirement of a double burner cook stove $=621780 / 11920 \mathrm{~kg} / \mathrm{month}$ $=52.16 \mathrm{~kg} / \mathrm{month}$

By ensuring the efficient use of LPG the monthly household consumption for a five member family could be reduced to $25 \mathrm{~kg} / \mathrm{month}$. It is possible because the heat transfer capability of LPG is $85 \%$ while that of natural gas is $70 \%$ which is $15 \%$ less.

The comparison of monthly usage and expense between natural gas and LPG are shown in Table 2 . LPG and natural gas could not be supplied simultaneously through the same distribution network because of difference in their physical properties. The regulators in natural gas and LPG distribution systems are also different. Moreover, the burners and appliances are dissimilar. The safety requirement of LPG distribution network and that of natural gas are not same. Therefore, the natural gas distribution system and LPG distribution system should be isolated from each other. Varieties of LPG bought and sold include mixes that are primarily propane, mixes that are primarily butane, and the more common, mixes including both propane $(60 \%)$ and butane $(40 \%)$, depending on the season-in winter more propane, in summer more butane. Propylene and butylenes are also present in small concentration.

Table 2. Replacing natural gas by LPG as a domestic fuel

\begin{tabular}{|c|c|c|c|c|c|c|c|}
\hline \multirow{3}{*}{$\begin{array}{l}\text { Present } \\
\text { consumption } \\
\text { (kg/Month) }\end{array}$} & \multirow{3}{*}{$\begin{array}{c}\begin{array}{c}\text { Natural } \\
\text { Gas }\end{array} \\
62.65\end{array}$} & \multicolumn{2}{|c|}{$\begin{array}{l}\text { LPG with respect to } \\
\text { present NG } \\
\text { consumption }\end{array}$} & \multicolumn{2}{|c|}{$\begin{array}{l}\text { LPG with respect to } \\
\text { present NG } \\
\text { consumption through } \\
\text { pre-paid meters }\end{array}$} & \multicolumn{2}{|c|}{$\begin{array}{l}\text { LPG by ensuring } \\
\text { efficient use }\end{array}$} \\
\hline & & \multicolumn{2}{|c|}{67.8} & \multicolumn{2}{|c|}{52.16} & \multicolumn{2}{|c|}{25} \\
\hline & & GOB & Private & GOB & Private & GOB & Private \\
\hline $\begin{array}{l}\text { Monthly rate } \\
\text { (BDT) }\end{array}$ & 800 & 4068 & 8678 & 3130 & 6677 & 1500 & 3200 \\
\hline $\begin{array}{l}\% \text { of present } \\
\text { natural gas rate }\end{array}$ & $100 \%$ & $508.50 \%$ & $1084.75 \%$ & $391.25 \%$ & $834.63 \%$ & $187.5 \%$ & $400 \%$ \\
\hline
\end{tabular}

Source: Authors' own calculation and Titas Gas T \& D Co. Ltd, 2017 
Table 3. Cost involved for LPG supply through pipe line network in KAFCO

\begin{tabular}{|c|c|c|c|}
\hline Major component & Unit & Quantity & Cost (million BDT) \\
\hline LPG Storage and Supply facility & Nos. & 2 & \multirow{10}{*}{6} \\
\hline Name of major items & & & \\
\hline LPG Cylinder (capacity 450 kg) & Nos. & 6 & \\
\hline Regulation and Evaporation facility & & & \\
\hline Regulator ( 15 bar to 1 bar) & Nos. & 2 & \\
\hline Evaporator (250 kg/hr.) & Nos. & 2 & \\
\hline LPG Distribution Network & & & \\
\hline 1 inch. $\Phi$ MS pipe & Meter & 1400 & \\
\hline $2^{\text {nd }}$ stage regulation & & & \\
\hline Domestic LPG regulator & Nos. & 34 & \\
\hline Total & & & 6 \\
\hline
\end{tabular}

The pressure, at which LPG becomes liquid, called its vapor pressure; likewise varies depending on composition and temperature. For example, it is approximately 220 kilopascals $(2.2$ bar) for pure butane at $20{ }^{\circ} \mathrm{C}\left(68{ }^{\circ} \mathrm{F}\right)$, and approximately 2.2 mega pascals (22 bar) for pure propane at $55^{\circ} \mathrm{C}$ $\left(131^{\circ} \mathrm{F}\right)$. LPG is heavier than air, and thus will flow along floors and tend to settle in low spots, such as basements. This can cause ignition or suffocation hazards if not dealt with carefully. To ensure its vapor form the supply pressure of LPG could not be raised more than 220 kilopascals (2 bars) in a distribution network. Moreover, vaporization of LPG is required to make sure its gaseous state. LPG Supply system requires fuel storage facility as well as handling system so space availability is an important factor for supplying LPG through pipe line network. To ensure the efficient use of LPG end user must be connected as metered customer.

At the backdrop of govt. ban on natural gas connection for domestic purpose, Karnaphuli Fertilizer Company Limited (KAFCO) has implemented a project aiming at supplying LPG through pipe line network as an alternative to piped natural gas. The authors has taken the feature and cost of this project as a basis for estimating cost of supplying LPG through pipe line network.

\section{LPG in Pipe Line Network Project in Karnaphuli Fertilizer Company Limited (KAFCO)}

KAFCO undertook a project to supply, install and operate a system to provide LPG through pipeline to the domestic users of 170 flats of 34 newly constructed building in 2012. The installation and commissioning cost of the project was BDT 6 million for 170 non-metered flats and one regulator was used for every 5 flats. The installation and commissioning cost per flat or burner was BDT 35,300 . Based on LPG private price BDT $128 / \mathrm{kg}$ of that period, LPG usage per flat per month was calculated $35.5 \mathrm{~kg}$ in winter and $22 \mathrm{~kg}$ in summer. The space required for both the LPG storage and supply system was 450.0 square feet (each system requires $(15 \times 15)=225$ square feet land area) and area. The components of that LPG storage and supply system are shown in the Table 3 .

\section{Pricing of Piped Natural Gas and LPG}

ADB (2013) came out with the findings that the existing gas allocation and pricing does not reflect economic values at all. Only $21.5 \%$ of the value of gas is captured in the power sector when the lower bound of the economic value is considered. But the bulk of the gas is allocated for power generation. In the fertilizer sector only $12 \%$ of the economic value is currently captured. Currently the highest price is charged for CNG, but it is only $66 \%$ of the willingness to pay (WTP). CNG sector gets only $6 \%$ of the gas. In the household sector current, price is only about $36 \%$ of the WTP for gas [5]. Household sector received only $12 \%$ of the gas [6]. All these indicate severe under pricing and inefficient allocation of natural gas in Bangladesh $[7,8]$.

Rahman and Islam (2014) suggest that the price of natural gas should be rationalized. This study reveals that the price of natural gas in Bangladesh should be Tk. 8.00 per cubic meter (2.71 USD/ MMBTU) with 9.90 per cent escalation of price per year. The distribution margin should be raised to Tk.0.166 per 1 Taka of gas price from Tk 0.086 taka of gas price $[4,9]$.This price rise will also enable the domestic consumers to absorb the higher price of LNG, which is also deemed to be an alternative to natural gas with a view to facing the dire scarcity of natural gas in not so distant future. An argument is also that the price of natural gas should be raised to a certain degree $[1,10]$.

The extra revenue thus obtained may be given to the LPG producers as subsidy or financial incentives. This situation may be termed as 'cross subsidy' 
Table-4: Comparative cost scenario for different LPG supply scenarios and piped natural gas of Bangladesh

\begin{tabular}{|c|c|c|c|c|}
\hline & $\begin{array}{l}\text { LPG in pipeline } \\
\text { network }\end{array}$ & $\begin{array}{c}\text { LPG in reticulated } \\
\text { system }\end{array}$ & $\begin{array}{l}\text { LPG in bottle } \\
\text { system }\end{array}$ & $\begin{array}{l}\text { Piped natural gas } \\
\text { for domestic use }\end{array}$ \\
\hline $\begin{array}{l}\text { Initial investment cost } \\
\text { per a domestic user }\end{array}$ & 55930.60 & 19512.29 & 2250.00 & 5500.00 \\
\hline $\begin{array}{l}\text { LPG cost/natural gas bill } \\
\text { per month per domestic } \\
\text { user }\end{array}$ & 1666.75 & 1666.67 & 2410.42 & 800.00 \\
\hline $\begin{array}{l}\text { LPG cost if exempted } \\
\text { from } 5 \% \text { CD \& } 5 \% \\
\text { AIT/natural gas bill per } \\
\text { month per domestic user }\end{array}$ & 1500.08 & 1500.00 & 2169.38 & 800.00 \\
\hline $\begin{array}{l}\text { Total cost per user } \\
\text { Total cost per user with }\end{array}$ & 57597.35 & 21178.96 & 4660.42 & 6300.00 \\
\hline $\begin{array}{l}\text { LPG cost exempted from } \\
5 \% \text { CD \& } 5 \% \text { AIT }\end{array}$ & 57430.68 & 21012.29 & 4419.38 & 6300.00 \\
\hline
\end{tabular}

Source: Authors' own calculation and Titas Gas T \& D Co. Ltd, 2017

This concept may be used to rationalize the LPG price for the common people. Thus, by giving access of LPG to them, the constitutional obligation of the government of ensuring access of common property to all could be complied with. Here it is worth noting that as per Bangladesh Customs National Tariff (Fiscal Year: 2016-2017) LPG price involves 5\% CD, 15\% VAT and 5\% AIT.

Our government is going to import LNG for reducing the demand-supply gap of natural gas. Already two LNG Floating Storage Re-gasification Unit (FSRU) terminals are scheduled to be constructed and in operation by mid 2018 and end 2018, with a capacity of 500 MMCFD for each terminal. The LNG price of Bangladesh is US $\$ 12$ per MMBTU in 2017 (2017 Gas Sector Master Plan of Bangladesh). Here, US $\$ 12 / 1 \mathrm{mmBTU}=$ BDT $12 \times 83 / 1 \mathrm{mmBTU}=$ BDT $12 \times 83 / 1000$ per CFT = BDT $12 \times 83 \times 35.3147$ $/ 1000$ per Cubic Meter $=$ BDT 35.17 per cubic meter. With a view to meeting our domestic demand of natural gas by imported LNG, monthly gas bill for a non-metered domestic user will be BDT 87.91 X 35.17 = BDT 3091.79 per month. Based on present gas consumption through prepaid meters, 67 Cubic Meters per double burner, monthly gas bill for a domestic user will be BDT 67 X 35.17 = BDT 2365.77 per month.

The pricing of piped gas for domestic use is cheap in Bangladesh. The WTP for piped natural gas for domestic use is much higher than its existing price. The authors' own calculation based on natural gas price data for domestic use since 1968, the average increase in the price of the piped natural gas for domestic use is only $14 \%$. This justifies the commensurate increase in price of piped gas for domestic use so as finance for lowering the LPG price with a view to facilitating its easy access to the common people of Bangladesh.

The costing of different methods of using LPG as an alternative of piped natural gas - LPG in pipeline network, LPG in reticulated system and LPG in bottle system - have been estimated for 1000 households. The cost of LPG in pipeline network has been calculated based on the cost involved for LPG supply through pipe line network in KAFCO. Analyzing the costs of different methods of using LPG as an alternative of piped natural gas it is found that initial investment is the highest and the lowest for the LPG in pipeline network and LPG in bottle system respectively, while LPG cost per month is the same for the LPG in pipeline network and LPG in reticulated system and the highest in bottle system. Noteworthy that reticulated LPG system is semi-automatic and in this case the LPG is stored in a central place of a multi-storied building and individual flat owner use metered LPG from that common source and thus safety risks are minimized. The comparative cost scenario for different methods of LPG supply and piped natural gas has been furnished in the table 4 .

\section{Conclusion}

LPG should be used as a commensurate alternative for piped natural gas, a scarce resource having more diversified and more value generating uses other than its domestic use. For LPG, reticulated system, which is a semiautomatic system, can be deemed to be an appropriate alternative for piped natural gas in domestic use. It is preferred to LPG bottle system because of serious safety issues intertwined with the later. LPG through pipe line network is a costly option indeed. 
Price of piped natural gas for domestic use should be raised to a level so as to make LPG use in reticulated system popular and at par with the ease and monthly bill for piped natural gas for domestic use. To render LPG as an alternative to natural gas, a set of policy issues must be addressed. These may be the following:

- Taxes/duties need to be reviewed at import and supply stage for the entire value chain.

- Price of LPG should be pulled down to a reasonable level so that the common people may enjoy access to it. This may be ensured by means of cross subsidy.

- Encourage increase of local LPG production. Some incentives may be given to the producers.

- Clear policy on Comparative Fuel Taxation and Pricing.

- Ban on manufacture and sale of small noncompany owned cylinders.

- Requalification of cylinders.

- Compliance to Codes \& Standards throughout the Distribution chain must be ensured

\section{References}

1. A.Rahman, Towards Promoting LPG as an Alternative to Natural Gas for Domestic Use, Energy and Power, (2014a, February), p. 19.
2. North American Combustion Handbook.(1986) Volume 1 Third Edition. p,12. North American MFG CO.USA.

3. Titas Gas Transmission and Distribution Company Limited: Annual Report of TGTDCL 2015, Dhaka

4. Rahman, A. (2014). Cost-Benefit Analysis of Introducing Natural Gas Pre-paid Meters in Titas Gas Transmission and Distribution Company Limited: An Analysis of 200,000 domestic users. (Master's thesis, Dhaka School of Economics). Dhaka.

5. ADB. (2013). Bangladesh: Tariff Reform and Inter-sectoral Allocation of Natural Gas. Dhaka: ADB.

6. Petrobangla.(2015). Annual Report of Petrobangla .Dhaka: Petrobangla

7. Petrobangla. (2006). Bangladesh Gas Sector Strategy Final Report. Dhaka.Bangladesh.

8. Petrobangla. (2012). Bangladesh Natural Gas Pricing Reform 2012. Dhaka: Petrobangla.

9. A. Rahman, and A K M N. Islam, International Journal of Development studies and Research, 3(2) (2014) 84.

10. Raihan, H. G. (April 2014). Opportunity Cost of Natural Gas Subsidies In Bangladesh. ADB 